ELUA

ISSN 2171-6692

Núm. 35, 2021, págs. 279-307

https://doi.org/10.14198/ELUA2021.35.14

\title{
LA ANTISEMIA EN LA TRADUCCIÓN: EL PROBLEMA DE LAS VOCES (SEMÁNTICAMENTE) BIFRONTES
}

\author{
ANTISEMIY IN TRANSLATION: THE PROBLEM OF (SEMANTICALLY) \\ BIFRONTAL VOICES
}

\author{
J. Agustín Torijano Pérez \\ Universidad de Salamanca, España \\ torijano@usal.es \\ https://orcid.org/0000-0002-8247-8168
}

\begin{abstract}
Resumen
Las vinculaciones semánticas entre palabras aparentemente próximas y entre sus significantes y sus significados son objeto de infinidad de estudios que tratan de resolver sus complicaciones y dificultades. Sin embargo, existe un sorprendente vacío científico en torno a la cuestión de lo que denominamos antisemia, por el hecho de tratarse de voces polisémicas que son capaces de contener simultáneamente un significado y su contrario, lo que supone un verdadero problema para aprendices y profesionales de la traducción, entre otras razones por la ausencia de herramientas semánticas que ayuden a establecer el valor correcto en cada contexto.

Este trabajo se centra en el análisis del concepto de antisemia, así como de ejemplos
\end{abstract}

\begin{abstract}
Semantic linkages between apparently upcoming words and their meanings and their meanings are the subject of countless studies that try to resolve their complications and difficulties. However, there is a surprising scientific void around the question of what we call antisemia, by the fact of polysemic voices that are able to contain at the same time a meaning and its opposite, which is a real problem for apprentices and translation professionals, among other reasons due to the absence of semantic tools that help to establish the correct value in every context.

This paper focuses on the analysis of the concept of antisemia, as well as some existing examples in Spanish, of his presence in contexts
\end{abstract}

Para citar este artículo: Torijano Pérez, J. Agustín (2021). La antisemia en la traducción: el problema de las voces (semánticamente) bifrontes. ELUA, 35: 279-307. https://doi.org/10.14198/ ELUA2021.35.14

Recibido: 10/07/2020, Aceptado: 23/10/2020

(C) 2021 J. Agustín Torijano Pérez

Este trabajo está sujeto a una licencia de Reconocimiento 4.0 Internacional

de Creative Commons (CC BY 4.0) 
existentes en español, de su presencia en contextos de mayor o menor frecuencia, y de las opciones de resolución de comprensión y traducción, especialmente para los profesionales de la traducción.

PALABRAS CLAVE: antisemia; semántica; traducción; heterosemánticos; polisemia. and situations of greater or lesser frequency, and resolution options of comprehension and translation, especially for translation professionals.

KEYWORDS: antisemy; contronyms; Semantics; translation; false cognates; polysemy.

\section{INTRODUCCIÓN: NI FALSOS AMIGOS NI ANTONIMIA NI POLISEMIA}

Los lexicógrafos y traductores sabemos muy bien que definir o elegir una palabra aislada a veces es tarea tan compleja como traducir un texto entero. Y si es laborioso conseguirlo solo con una, cuánto más no lo será al abrir el foco de esa unidad léxica para relacionarla con las otras que comparten con ella similitudes de comportamiento, de significante o de significado, porque entonces la empresa se convierte en un trabajo hercúleo, no siempre recompensado con resultados satisfactorios.

Son muchos los estudiosos que han abordado esta espinosa cuestión de las relaciones léxicas (entre las que tradicionalmente se han incluido la antonimia, la hiperonimia, la hiponimia, la cophiponimia, la sinonimia, la polisemia, la homonimia o la paronimia), por lo que remitimos a la ingente literatura al respecto, si bien parece conveniente recordar algunas conclusiones de dos autores como M. Casas Gómez y M. D. Muñoz Núñez, que han dedicado muchos trabajos a tratar de acotar, definir y explicar algunos de aspectos fundamentales, y muy especialmente algunos relacionados con la polisemia y la homonimia. A este respecto, ya en 1992, especificaban lo siguiente:

Por otra parte, si por relación léxica entendemos sólo las conexiones que en el sistema de la lengua contraen los significados de signos, hemos de concluir que ni la polisemia ni la homonimia constituirían relaciones semánticas, dado que lo serian únicamente desde la óptica del significante, pudiendo ser estudiadas con independencia del plano del contenido. Con tales presupuestos teóricos, las mencionadas relaciones léxicas quedarían reducidas, así pues, a aquellos fenómenos paradigmáticos que pueden describirse solamente desde el punto de vista del significado, como son la sinonimia, la hiperonimia-hiponimia y los diferentes subtipos de relaciones antonímicas. (1992:150)

Por lo que respecta a nuestro estudio, analizaremos las dificultades de comprensión y, por ende, de su eventual traducción, que generan el fenómeno denominado de los falsos amigos $^{1}$, la antonimia y la polisemia, con los que la antisemia comparte solo algunos rasgos, pero que $n$ absoluto debería confundirse con ellos.

Las lagunas bibliográficas existentes en la actualidad en torno a esta última suponen una dificultad a la hora de definirla, paso previo y esencial para poder estudiarla con cierta profundidad. Su parentesco con otros fenómenos semánticos ha dificultado su identificación, descripción y definición, por lo que se impone lo que podríamos denominar una definición negativa, a la manera en que, mutatis mutandis, los teólogos medievales trataban de definir a Dios. Como es sabido, y tomando como base a los neoplatónicos del siglo III, con Plo-

1 Ver infra para las diferentes denominaciones que ha recibido el fenómeno. 
tino (205-270) como máximo representante, Tomás de Aquino (1225-1274) en su Summa Theologica (1994, vol. I, p. 107-11) desarrolló la denominada vía negativa ${ }^{2}$, para intentar definir al Ser supremo a partir de las características conocidas en el ser humano y en la naturaleza, considerando siempre que Dios no podía compartir esos rasgos que el escolástico consideraba impropios de la divinidad.

Procediendo del mismo modo, trataremos de definir la antisemia a partir de constatar los rasgos que no comparte con los tres fenómenos semánticos mencionados, a fin de lograr una definición, descripción y clasificación válidas para ulteriores investigaciones.

\subsection{La antisemia no son falsos amigos}

Las similitudes morfológicas y semánticas entre pares de palabras aparentemente próximas han sido materia de un sinnúmero de estudios, análisis y denominaciones, desde muy diferentes perspectivas y finalidades, de tal manera que forman parte ya de las dificultades habituales de traductores e intérpretes. Es especialmente complicado este problema de las confusiones semánticas por igualdad o proximidad en los significantes de dos lenguas más o menos próximas.

En efecto, los denominados falsos amigos constituyen un fenómeno semántico prácticamente irresoluble, especialmente entre pares de idiomas con una corta distancia lingüistica, como pueden ser el español con el italiano, o más aún, con el portugués, cuyos estudiosos han acuñado el término casi específico de heterosemânticos, por tratarse de un par de lenguas entre las que el problema adquiere dimensiones inabarcables y parece generar su propia terminología. Sin embargo, y de forma general, y como recogen Vita Pacheco (2005: 117-124), M. Amadeu Sabino (2006: 251-263) o L. Carlucci y A. Díaz Ferrero (2007: 159190), no es extraño encontrar en la literatura científica sobre esta materia un inextricable laberinto conceptual que deja traslucir esa dificultad de solucionar los problemas de aprendizaje y traducción que suponen estos cientos de pares de palabras que tanto confunden a aprendices y a traductores de ambas lenguas. Nos referimos a términos como los de calcos léxicos, cognados engañosos, falsas analogías, falsos afines, falsos amigos, falsos cognados, parónimos o el explícito de trampas semánticas.

La antisemia no es, por tanto, un problema de falsos amigos, porque aquella se produce en el seno de una sola palabra, a diferencia de los falsos cognados, que necesitan del concurso de, al menos, dos significantes iguales o muy similares que inducen a interpretarse como semánticamente equivalentes.

\subsection{La antisemia no es antonimia}

Como ocurre con los anteriores, la antonimia precisa también de la presencia de dos o más significantes, algo que ya constituye una diferencia evidente con respecto a la antisemia. Pero, además, aquella se produce por la coincidencia en el sistema de dos significados o acepciones antagónicos que lo son en tanto que denotan realidades opuestas, como podrían ser similares en el caso de la sinonimia. Es decir, se trata de un fenómeno que podríamos considerar independiente de cada palabra y cuyos significados se diferencian como algo extrínseco a la carga

2 También conocida como teología negativa. 
semántica de cada una de ellas, fruto de la comparación o contraste que descubre el hablante o el lingüista a partir de los comportamientos semánticos de dos o más palabras diferentes.

Por otra parte, y como señala C. Varo (2007: 164), esta organización bipolar de los antónimos tan solo tiene cabida "dentro de un marco de explicación ligado a la pragmática, bajo determinados condicionantes especiales de carácter social, juicios de valor, etc.”.

Así pues, pese a que tanto la antinomia como la asntisemia compartan el concepto de 'contrario', la comparación no trasciende este hecho, pues cada fenómeno consta de características diferentes.

\subsection{La antisemia no es polisemia}

A diferencia de los dos casos anteriores, la polisemia no se produce entre dos significantes, sino que basta con que uno solo reúna más de un significado para que el hablante y el profesional de la lengua se encuentre en la encrucijada de elegir cuál de los posibles valores semánticos debe aplicar a un significante en un contexto determinado. Se trata de un fenómeno vinculado a las denominadas destrezas pasivas ${ }^{3}$, esto es, lectura y comprensión oral, toda vez que el receptor necesita desentrañar un código polivalente, en muchos casos sin más herramientas que la propia intuición, la analogía, el supuesto conocimiento sociolingüístico o la similitud con otras lenguas.

La polisemia es la causante de no pocos problemas a los traductores, al tener que decidir entre qué acepción o, peor aún, qué sentido adquiere determinado significante en el texto de origen (TO) en según qué contexto lingüístico o pragmático. A modo de ejemplo, recordemos que voces de altísima frecuencia de uso en español como pasar o mano reúnen tal cantidad de acepciones que sus artículos lexicográficos constituyen verdaderos tesauros o repertorios enciclopédicos, en muchos casos comparables a descripciones acerca de la concepción de la vida y la cultura de esa lengua, cristalizada a partir del léxico y de las cargas semánticas.

En el caso de pasar, por ejemplo, la 23. a edición del DLE $(2018)^{4}$ recoge un total de $\mathbf{6 4}$ acepciones y $\mathbf{1 4}$ locuciones y expresiones, algunas de las cuales son tan desconocidas e insospechadas, incluso para hablantes instruidos, como pueden ser las siguientes:

25. tr. Desecar algo al sol, o al aire o con lejía.

o

59. prnl. Dicho de la lumbre de carbón: Encenderse bien.

Por su parte, el sustantivo mano (sin considerar la aféresis de hermano, na) ${ }^{5}$ reduce el número de acepciones a $\mathbf{3 6}$ (aun siendo la mitad que las del ejemplo anterior, el número es ciertamente elevado), pero eleva el de locuciones expresiones nada menos que a 371, lo que puede derivarse en un sinnúmero de lecturas y traducciones erróneas.

Pero no es ese el único problema, dado que, a la enorme cantidad de acepciones posibles y correctas del sustantivo, debe añadírsele el hecho de que algunas de ellas aparecen en

3 En el caso de los falsos amigos, las destrezas involucradas también son las activas (escritura y producción oral), dado que, además de descodificar un discurso dado, el emisor debe elegir entre significantes que él considera equivalentes, entre las lenguas en conflicto, para expresar un contenido.

4 DLE: s. v. pasar.

5 DLE: s. v. mano. 
posiciones relativamente altas en el orden de las acepciones, lo cual puede dar a entender de su alta frecuencia de uso o vigencia (no sería el caso de "desecar algo al sol, o al aire o con lejía" del ejemplo anterior, colocado en una poco preeminente posición $25^{\mathrm{a}}$ ), como observamos en la acepción $6^{\text {a: }}$

\section{6. f. Trompa del elefante.}

o, solo un poco más abajo, en la $14^{\mathrm{a}}$ :

14. f. Entre tahoneros, número de 34 panecillos que componen la cuarta parte de una fanega de pan.

Evidentemente, para que se dé la antisemia, es necesaria una polisemia que genere, al menos, dos significados distintos, pero eso no quiere decir que sean opuestos, en cuyo caso ya estaríamos hablando del fenómeno que nos ocupa.

\section{ORÍGENES Y TERMINOLOGÍA}

Ya hemos mencionado más arriba (1. Introducción) las lagunas bibliográficas en torno a la antisemia, si bien ha habido loables intentos de sistematizar el concepto y hasta de generar un término válido y consensuado - de la misma forma que se aceptaron en su día homonimia, sinonimia, polisemia o antonimia- e, incluso, de determinar el origen de los primeros estudios del fenómeno.

En efecto, la consideración de un tratado primigenio no cuenta con el consenso de la comunidad científica porque más parece vinculado a la lengua de la que se trate que al fenómeno en sí mismo, en un problema terminológico que guarda similitudes con el ya mencionado de los falsos amigos.

Así, los investigadores italianos (Beccaria, 2004: 273-274) establecen el origen en los estudios del teólogo y orientalista oxoniense Edward Pocock (o Pococke) (1604-1691), quien ya utilizó el término enantiósema (del que nos ocuparemos más adelante) para referirse a palabras que presentaban significados opuestos, en lenguas como el hebreo, el arameo o el árabe.

Sin embargo, para los estudiosos anglófonos, el término originario, en este caso autantonyms [sic], fue acuñado por el neoyorkino Joseph T. Shipley (1893-1988), profesor de lengua y literatura inglesas, crítico y dramaturgo, traductor y autor de muchos estudios sobre etimología, historia, teatro, etc., en su obrita Playing with words ${ }^{6}$, publicada en 1960. Para complicar más aún el conflicto terminológico, en la misma lengua se habla también de auto-antonyms ${ }^{7}$, autoantonyms (sin apócope en el elemento compositivo), de antagonyms ${ }^{8}$, de enantiodrome, de self-antonyms, de self-contradictory, de antilogy y hasta de Janus-faced

6 Se trata de un librito de 186 páginas con más de 200 juegos de palabras, anagramas, juegos para crucigramas, poemas, metátesis graciosas, proverbios, parodias, etc.

7 Propuesto en 1994 por el lingüista norteamericano Alex Eulenberg, de la Universidad de Indiana, en su artículo "Words that are their own opposites".

8 Creado, a su vez, por el británico Charles N. Ellis: "Antagonyms: Derivation of the word "antagonym" by the author", publicado en la Universidad de Michigan, en 1999. 
words $^{9}$, o de contranyms y de su variante más correcta contronyms, término acuñado por J. Herring (1962: 8), que él mismo define de la siguiente manera:

[...] any word which is used in two senses which seem to contradict each other.

Por su parte, en la semántica germánica se adoptó el préstamo del inglés Janusword en la forma Januswort, si bien se considera que fue el lingüista romanista alemán Andreas Blank (1961-2001) quien estableció en $2001^{10}$ el término científico alemán exacto de Autoantonymie (por entender que estas palabras se comportan como un antónimo de sí mismas), otro préstamo del inglés, junto a Antagonym. Además, en algunas ocasiones se opta por los calcos das Kontranym o der Gegensinn (literalmente 'sentido contrario'), presente en la locución im Gegensinn, traducible por 'en sentido contrario, en la dirección opuesta'.

Por lo que respecta al español, los problemas terminológicos son peores que para las otras lenguas, porque la Academia, que define desde hace decenios los demás fenómenos semánticos, no incluye ninguna entrada en su lemario, ni, por tanto, propone un término para definir la antisemia.

Parece carecer de explicación lógica el hecho de que, dado que nos encontramos ante un fenómeno ya descrito desde hace siglos (cf. supra Edward Pocock, s. XVII), presente en prácticamente todas las lenguas y perfectamente susceptible de ser descrito, la Academia no haya decidido, en alguno de esos aluviones de neologismos incorporados que la institución lleva a cabo cada cierto tiempo, incluir una entrada que recoja y defina el fenómeno, no ya solo en el diccionario general, sino ni siquiera en el apartado del Diccionario panhispánico de dudas dedicado a los “Términos lingüísticos", donde, pese a volver a aparecer los fenómenos semánticos ya mencionados, no hay la mínima referencia al que nos ocupa.

En efecto, pese a lo que sucede en tantos diccionarios, glosarios o vocabularios más o menos especializados en idiomas próximos al nuestro, tenemos que dejar constancia del intento, a todas luces insuficiente, del Diccionario por cubrir ese vacío lexicográfico mediante la inclusión en su lemario de dos conceptos tradicionales vinculados con el contrasentido, pero que no son, en absoluto, sustitutos ni aun parciales del fenómeno que nos ocupa. Se trata de las voces antilogía y antifrasis.

Define el $D L E$ la antilogía como la "Contradicción entre dos textos o expresiones" "11 y es evidente que la presencia del plural invalida por completo su identificación con la antisemia, por el simple hecho de que en esta la contradicción o el contrasentido debe producirse en una única palabra o expresión, no en más.

Por su parte, la antífrasis es definida, en retórica, como la "Designación de personas o cosas con palabras que signifiquen lo contrario de que se debiera decir"12, concepto que tampoco se adecua porque no hace referencia a ambos significados al mismo tiempo, requisito indispensable para poder hablar de antisemia, sino de un significado que sustituye al otro,

9 Expresiva forma de referirse al fenómeno, creada por R. Lederer (1998, pp. 86-95), en alusión al carácter bifronte del dios romano Jano, que daba nombre a iānuārius (enero), por ser el primer mes del año, que mira al pasado y al futuro.

10 Einführung in die lexikalische Semantik für Romanisten (2001) [Introducción a la Semántica léxica para romanistas].

11 DLE: s. v. antilogía. El subrayado es nuestro.

12 DLE: s. v. antifrasis. 
pese a que en la denominada Wikilengua se afirme que "el origen de la enantiosema está a menudo en una figura denominada antífrasis"13.

Podría afirmarse que los intentos académicos, directos o indirectos, de abordar el fenómeno parecen restringirse casi exclusivamente a los boletines digitales (las "recomendaciones diarias") y radiofónicos de la Fundéu ("El español urgente con Fundéu”), que cuenta, como se afirma, con el asesoramiento de la Real Academia, quien menciona y hasta define y explica el fenómeno mediante el préstamo enantiosemia, pese a que se refiera a las voces afectadas como autoantónimos, opción, en nuestra opinión, poco recomendable. En efecto, si de lo que se trata es de armonizar, homogeneizar y hasta facilitar el conocimiento lingüístico por parte de los propios usuarios del idioma, no parece tener mucho sentido que, si los fenómenos ya asentados en la comunidad hispanohablante como antonimia, homonimia, polisemia o sinonimia producen términos antónimos, homónimos, polisémicos o sinónimos (o sinonímicos), respectivamente, el fenómeno que pretenden denominar enantiosemia genere términos autoantónimos. Por una mera razón de sistematización científica, debería pensarse en un sustantivo para el fenómeno y un derivado de aquel para los casos afectados por él, como desarrollamos a continuación.

En lo que atañe a la terminología, tampoco han gozado de demasiada fortuna ni el concepto ni una voz que lo nombre, ni siquiera en la que podría considerarse la biblia de la terminología en español, el clásico Diccionario de términos filológicos, de F. Lázaro. En efecto, a pesar de las numerosas ediciones y reimpresiones, no se ha mejorado sensiblemente esta cuestión.

Es innegable que obra ha ido aumentando y renovándose, especialmente en las ediciones de 1963 y de 1968 (además de innumerables reimpresiones), como se observa en el hecho de que en las primeras ediciones de 1953 se pasara de la entrada enálage a encabalgamiento, sin apenas mención de enantiosemia ni de autoantónimos. Sin embargo, y pese a dichas mejoras, en ediciones posteriores (por ejemplo, en la tercera, séptima impresión, de julio de 1987), el resultado no arroja demasiada luz sobre el asunto: por un lado, y aunque ya se incluye la voz enantiosemia, su definición reza literalmente: "Término con que se designa también la antonimia*"14; y, por otro, porque la remisión a que hace referencia el asterisco es igualmente descorazonadora, dado que, se nos ofrecen dos acepciones bajo la misma entrada, la segunda de las cuales -después de la definición canónica ${ }^{15}-$, recoge lo siguiente:

2.- Fenómeno que se produce cuando un vocablo posee dos significados opuestos. Huésped significa a la vez 'el que hospeda' y 'el que es hospedado'. Muy leído es un libro que leen muchos lectores, pero también un lector que lee muchos libros.

Es decir, se colocan bajo el mismo término la significación contraria de dos vocablos diferentes y la oposición semántica que genera un único vocablo, lo cual alcanza el mismo rigor científico que obtendríamos de equiparar la polisemia con la homonimia.

13 Wikilengua: s. v. : enantiosemia. Es cierto que la Wikilengua, según su propia página web, "no es una obra de referencia $[\ldots], \mathrm{n}[\mathrm{i}]$ es una obra normativa", pero no lo es menos que, como continúa el texto, "[L]a Wikilengua está promovida por la Fundéu BBVA [...]", y que "la Fundéu BBVA es una fundación [...] que trabaja asesorada por la Real Academia Española".

14 DTF: s. v. enantiosemia.

15 DTF: s. v. antonimia. 
En la actualidad, y tomando como referencia una de las obras de consulta de mayor solvencia como es el Diccionario de lingüística moderna, observamos que esta inmensa nebulosa conceptual y terminológica en torno a la antisemia en español muestra un reflejo nítido en el hecho de que, ni aun en su segunda edición, de 2004, haya la menor referencia a este asunto (pasa de empirismo a enclisis -sin rastro de enantiosemia - y de aumentativo a autoincrustación -sin huella de autoantónimos-), pese a que, como cabía esperar, se recojan, definan, clasifiquen y ejemplifiquen los tradicionales conceptos de antonimia, homonimia, sinonimia ${ }^{16}$, etc.

Se trata, pues, de un panorama poco halagüeño, especialmente si de lo que se trata es de nombrar y definir de manera rigurosa, clara y homogénea un fenómeno que, como hemos visto, parece acompañar a las lenguas desde su nacimiento.

\section{UNA PROPUESTA TERMINOLÓGICA}

Como queda dicho, la presencia del fenómeno en nuestra lengua es testimonial y confusa hasta el extremo de tener que constatar su ausencia en el diccionario de referencia del idioma. Esta falta de presencia conceptual podría ser, si bien se considera, causa y efecto a un tiempo de las deficiencias terminológicas, que se resuelven con meros calcos léxicos, aunque ni siquiera de forma homogénea. Además, la apuesta de la Fundéu por enantiosemia para designar el fenómeno y por autoantónimos para nombrar los casos, no solo presenta esa discrepancia y asimetría terminológica entre el fenómeno en sí y la adjetivación de cada uno de los casos afectado por el propio fenómeno (que no se produce, como veíamos arriba, entre los demás fenómenos semánticos), sino que, además, ambos términos resultan ciertamente sesquipedáli$\cos ^{17}$ por aglutinación de elementos compositivos que podríamos considerar superfluos.

3.1. En el primer caso, no es difícil discernir que enatiosemia procede de la composición, por un lado, de los elementos griegos $\dot{\varepsilon} v$ y $\breve{\alpha} v \tau$ thos, si bien aparece a veces como un solo

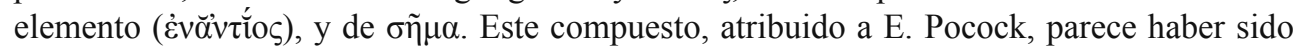
tomado como préstamo por muchas lenguas, sin la más mínima reflexión sobre el hecho. Sin embargo, creemos que en nuestra lengua esta opción, además de por todo lo adelantado más arriba, presenta dos problemas.

Por un lado, el primer elemento compositivo (o el conglomerado) enantio-, usado para designar el valor de 'opuesto, contrario', parece responder a un intento de hipercultismo redundante (lo que Aurelio Arteta magistral e ingeniosamente denominó archisílabo $^{18}$ ), que nada aporta, salvo cierta pedantería, al término. No se trata de evitar la acumulación de prefijos o de elementos compositivos necesarios, como puedan ser los casos de antiposmodernis-

16 DLM: s. v. antonimia, antónimo, etc.

17 Wikilengua propone, con el mismo esquema, los términos sesquipedalismo para el fenómeno y archisílabos para los casos, con los mismos problemas que estamos analizando: no hay la más mínima similitud morfológica entre ellos y, además, el segundo término no aparece recogido en el DLE.

18 En 1995 el profesor de Filosofía Política y Teoría de la Democracia Aurelio Arteta acuñó esta voz para estas palabras "que se van incorporando al uso cotidiano del hablante, preferidas por su mayor largura o inventadas a fuerza de estirar el número de sus sílabas", y que son las herederas de las sesquipedalia verba de Horacio, descritas así en su Arte poética: "palabras ampulosas, alargadas a base de la acumulación sufijos y prefijos, vestidas de una falsa pompa o de un dudoso cientifismo que al parecer las hace sabrosas para su emisor y cautivadoras para sus oyentes": https:/www.elartedepresentar.com/2011/11/huye-de-los-archisilabos-en-tus-presentaciones/ 
ta, antirreeleccionista, cuasiposmoderno, exvicepresidente, preposfranquismo, proneoliberalismo, requetesuperguapo, etcétera, recogidos en la Ortografía de la Academia (2010: 543; 2.2.2.3. Combinación de prefijos) para ejemplificar acerca de la correcta forma de escribir estas palabras, una vez eliminado el guion o la separación que la misma institución prescribía en publicaciones anteriores, dado que, en todos estos ejemplos, cada uno de los prefijos aporta un valor semántico necesario, lo cual es más que dudoso en el caso que nos ocupa.

Se trata de evitar lo que en la nomenclatura de Arteta podríamos denominar un archiprefijo, al que se ha opuesto siempre la Academia como se constata por el siguiente dato objetivo: no hay ni una sola entrada en el lemario oficial que presente la forma enant $(i)_{-}$, salvo los casos de enante (una hierba venenosa de flores blancas y raíz tuberosa) ${ }^{19}$ y enantes ('recientemente' en algunas zonas hispanoamericanas y un uso vulgar y anticuado del adverbio temporal 'antes') ${ }^{20} 21$, frente a las 270 entradas con el prefijo anti- (para 'opuesto' o 'con propiedades contrarias', como antinomia, por ejemplo), entre las que no deben contarse las 20 voces que corresponden a los valores relativos a la antigüedad, las Antillas (y Antioquia, en Colombia), los anticipos y las formas antiguas de ante-('delante'): antipara, antiparras o antipendio (un velo o tapiz que tapa los soportes y la parte delantera de algunos altares). En resumidas cuentas, si nuestra propuesta de antisemia recoge perfectamente un significado diáfano y evidente, no parece haber ninguna razón etimológica, morfológica, terminológica ni semántica que haga necesario el palabro (1. m. coloq. Palabra rara o mal dicha $)^{22}$.

3.2. El segundo problema al que nos referíamos más arriba es doble: por una parte, nos encontramos con la discrepancia morfológica entre el término importado para el fenómeno (enantiosemia) y los casos afectados por él, los autoantónimos, divergencia que, como hemos dicho anteriormente, no sufren los demás fenómenos semánticos, que habría producido un más coherente -aunque archisílabo-enantiosémicos, solución que, sorprendentemente, nadie ha propuesto. Y, por otra, porque volvemos a toparnos con otro caso sesquipedálico innecesario, toda vez que autoantónimo está formado por esa aglutinación de elementos compositivos (tan propia de la terminología de las ciencias positivas y de la medicina) que parecen darle al término una dificultad totalmente ajena al concepto, aparte de que auto- exigiría otra voz simétrica que comenzara por hetero- (como autónomo frente a heterónomo, autótrofo frente a heterótrofo, o autópsido frente a heterópsido ${ }^{23}$ ), algo así como *heteroantónimo, que sería, además de otro término sesquipedálico, una redundancia evidente para referirse a lo que conocemos tradicionalmente como antónimos; aunque también podría imaginarse un hipotético *aloantónimo, por el valor de ő $\lambda \lambda \lambda_{0}$ ( ('otro', 'distinto'), que volvería a incurrir en los errores anteriormente descritos.

Así pues, por todas las razones expuestas anteriormente, hablaremos del fenómeno como antisemia $^{24} \mathrm{y}$ de las voces afectadas como antisémicos, que, mōre Acadēmīae, podría quedar definida del siguiente modo:

19 DLE: s. v. enante.

20 DLE: s. v. enantes.

21 En algunos glosarios o diccionarios técnicos se recogen enantiómero, ra y enantiomorfo, fa, dos tipos de isómeros químicos: DMBHE: s. v. enantiómero, ra y enantiomorfo, fa.

22 DLE: s. v. palabro.

23 DLE: s. v. autópsido y heterópsido.

24 Podría haber sido también válida la solución antinomia, pero es voz ya dotada de significados relativos a las leyes, y referida a las contradicciones entre principios legales o principios razonables: DLE: s. v. antinomia. 
Si antónimo, ma se explica así:

De anti- y -ónimo.

1. adj. Ling. Dicho de una palabra: Que, respecto de otra, expresa una idea opuesta o contraria, como virtud y vicio, claro y oscuro o antes y después. U. t. c. s. m.

Y polisemia se recoge de este modo:

De poli-1 $^{1}$ y el gr. $\sigma \tilde{\mu} \mu \alpha$ sêma 'significado'

1.f. Ling. Pluralidad de significados de una expresión lingüística.

Entonces, antisemia podría definirse así:

De anti- y el gr. $\sigma \tilde{\eta} \mu \alpha$ sêma 'significado'.

1. f. Ling. Oposición de significados de una misma unidad léxica, como en alquilar.

Nuestra propuesta, por todas las razones expuestas anteriormente, encuentra sus fundamentos en las nuevas perspectivas que ofrece la Semántica léxica actual, pues su ampliación hacia la complejidad de los rasgos extralingüísticos ratifica la certeza de que ya no es posible hablar de teoría semántica per se, dado que, en opinión de M. Casas y M. Hummel (2017), "no existe semántica sin forma material que la soporte" (2017:884).

En efecto, como afirman estos autores:

[1]a actual semántica léxica se diferencia, precisamente de la lexicología clásica, por la adición de nuevos contenidos [...], como el extenso campo de la formación de palabras, la neología y el análisis de los neologismos, el estudio semántico y la práctica fraseográfica de las locuciones, las bases conceptuales y epistemológicas de la terminología y las técnicas metodológicas de la terminografía, la diversidad de aspectos que compete a la variación lingüística desde el punto de vista semántico, la atención merecida que en los últimos años se presta a la dimensión sintagmática del léxico, especialmente en el ámbito de las colocaciones, y la reciente investigación de la dimensión neurocognitiva del léxico. (2017:886)

Y es precisamente la exigencia de esa forma material y de la precisión científica de su nomenclatura, así como de esas "bases conceptuales y epistemológicas de la terminología y las técnicas metodológicas de la terminografía" la que nos determina a proponer un término exacto, sencillo y unívoco, porque es obligación de la ciencia en español hacer valer sus potencialidades intrínsecas sin depender tanto de eventuales traducciones de otras lenguas.

\section{PREEXISTENCIA DEL TÉRMINO}

La existencia de la voz propuesta parece encontrar sus orígenes en autores chilenos, y su mera existencia parece confirmar la facilidad de su estructura morfológica. La primera referencia encontrada de la voz corresponde a un trabajo de Ambrosio Rabanales, titulado "Recursos lingüísticos, en el español de Chile, de expresión de la afectividad", publicado en 1958 en el Boletín de filología de la Universidad de Chile. Se trata de un trabajo descriptivo, del que la crítica del momento afirmó: 
En todos los recursos estudiados, el aspecto positivo o negativo de la afectividad dependerá de la entonación, de la situación contextual o de la significación del término. El autor ilustra ampliamente cada uno de los recursos estudiados, con ejemplos del habla o de escritores criollistas que reflejan el lenguaje oral de las clases sociales que se estudian. El trabajo incluye bibliografía de las obras literarias consultadas y un índice de materias (BICC, 370).

Este estudio, un verdadero alarde de creación terminológica, trataba de describir esos recursos lingüísticos, clasificados en fonéticos, morfológicos, sintácticos y, por último, léxicos, que clasificaba de la siguiente manera:

[...] 4. Recursos léxicos:

I. Homosemia. II. Hipersemia, III. Antisemia. IV. Cacosemia. V. Calosemia. VI. Perisemia.

VII. Hiposemia. VIII. Polisemia. IX. Palinsemia. X. Parasemia. (La negrita es nuestra).

Como se observa fácilmente, ninguna de las voces acuñadas por Rabanales existía en la época y, sin embargo, a poco que se conozca del significado de los prefijos y otros elementos compositivos utilizados, puede deducirse, al menos aproximadamente, el valor de esos "recursos léxicos". Para el caso que nos ocupa, antisemia era la acuñación personal del autor para lo que se entiende tradicionalmente como antífrasis, pese a que en realidad no se trata del mismo fenómeno, como veíamos más arriba (3. Orígenes y terminología).

Casi 15 años más tarde el término se carga de una connotación vinculada con la psiquiatría, utilizado por el célebre neurólogo, psiquiatra y escritor español Carlos Castilla del Pino en su ya clásica Introducción a la hermenéutica del lenguaje (1972), en la que define así el término con un valor realmente próximo al que entendemos debería tener en ámbitos semánticos:

Utilizamos el vocablo antisemia en lugar de antonimia, porque en éste la oposición de significados concierne a pares de lexemas, como "bueno"- malo", "agradable""desagradable", etc. La oposición antisémica radica, pues, en el mismo significante, que contienen significados opuestos. Esto se ve claro, más que en el plano de la lingüística, en el de la expresión extralingüística: así un síntoma, por ejemplo un intento de suicidio, puede ser una expresión tanto de una instancia a la autodestrucción como de un requerimiento de afecto por parte de un objeto, y, por tanto de autoconservación. (p. 50).

Consciente de la necesidad de crear un término para explicar esa bifrontalidad de una misma palabra, C. Castilla ofrece variantes lingüísticas para el tecnicismo, recogidas por J. J. Segarra Valls en el "glosario multilingüe" del anexo de su obra (2010: 346):

Inglés: antisemia; alemán: Antisemie; francés: asntisémie y catalán: antisemia.

Un eco de la obra de A. Rabanales lo encontramos en otra autora chilena, Liliana Belmar, en su artículo "La denominación como proceso semántico en una historieta chilena", de 2006, en el que analiza las maneras de nombrar y de referirse a los personajes que aparecen en los libros ilustrados con dibujos del tipo cómic o tebeo, que publicó en la revista Contextos, estudios de humanidades y ciencias sociales. En este caso, parece repetir la peculiar asignación semántica al término, dado que, a juzgar por las explicaciones de la autora, con antisemia se refiere a lo que el DLE define exactamente con antifrasis (cf. supra): 
Entre los recursos léxicos más usuales que se presentan en esta revista, están los siguientes casos que A. Rabanales llama:

1) Antisemia, en que se expone la idea contraria de lo que se expresa el nombre como son las ironías, por ejemplo.

- Ungenio González'. Eugenio, de nariz aguileña, dientes superiores sobresalientes, y con una gota de saliva que siempre cuelga de su labio inferior. Es uno de los mejores amigos de Condorito, y el más torpe del grupo; es el que siempre tiene una historia absurda que contar. Debido a este rasgo, se lo llama Ungenio, es decir, "es un genio" (2006: 7).

Como cuarta referencia a la existencia de la voz, de nuevo entre autores chilenos, encontramos el artículo de B. Cárdenas Maragaño ("Los apodos: individualizadores conceptuados"), de 2015, en el que parece confirmar la inestabilidad semántica del término, dado que en algunos párrafos lo identifica con la ironía o con la antífrasis (o antifrase: 'Modo de expresión consistente en exponer una idea por la idea contraria, con entonación ordinariamente irónica' $)^{25}$, prácticamente sinónimas en el Diccionario de términos filológicos de F. Lázaro ${ }^{26}$ :

Fernando de Aragón e Isabel de Castilla, su mujer, fueron piadosamente llamados "Los Reyes Católicos", (se trata más bien de una antisemia) sin que en este caso el apodo alcance a dar cuenta de la poco católica confiscación que hicieron de todas las propiedades de los judíos, al tiempo de expulsarlos en 1492. (2015: 12)

El apodo también puede serlo de una realidad extrapersonal, como "La villa miseria" que es una antisemia con la que el hablante identifica un barrio residencial de hermosas y valiosas casas. (2015: 13)

Aunque en otros, el autor usa antisemia para explicar una especie de híbrido de esa ironía con una evidente metonimia, lo cual es una evidente contradictio in terminis:

Existen otros que poseen apodos cándidos, por ejemplo, uno de los más feroces asesinos del cartel de la droga en México, Édgar Valdez — apodado por medio de una antisemia-, "La Barbie", que por sus ojos azules se le asoció a la esbelta muñeca. (2015: 12) ${ }^{27}$

\section{TIPOLOGÍA DE LA ANTISEMIA: UNA PROPUESTA DE CLASIFICACIÓN}

Asentada la morfología y la semántica de la voz, procedemos a continuación a establecer una tipología básica, conducente a completar la comprensión real y práctica del fenómeno que estamos estudiando. En nuestra clasificación, establecemos dos grandes apartados generales, vinculados, por una parte, con causas exógenas o por calco semántico y, por otra, con causas endógenas. $\mathrm{Y}$ es dentro de este segundo apartado donde distinguimos las siguientes cinco subclases: por evolución morfológica o del significante, por evolución semántica ( $h i$ peronimia o imprecisión semántica), sintáctica, dialectal y, por último, intencional.

Dado que los casos que ejemplifican cada uno de los tipos son bastante transparentes, se observará que apenas es necesaria una básica explicación teórica que identifique y defina cada una.

25 DLE: s. v. antifrasis.

26 DTF: s. v. ironía y antifrase [sic].

27 El subrayado de cada una de las tres citas es nuestro. 


\subsection{Antisemia por causas exógenas o por calco semántico}

Este primer gran epígrafe recoge la antisemia producida por la llegada e incorporación al español de un significante homónimo procedente de otra lengua (con su significado correspondiente) que entra en conflicto semántico con la voz patrimonial porque aporta un significado que no solo puede ser diferente, sino que llega eventualmente a ser el opuesto, bien propio, bien contextual.

Antisemia por causas exógenas (calco léxico): un significante homónimo se incorpora al español, pero aporta un significado diferente, que llega a ser opuesto contextual.

Un ejemplo paradigmático de este tipo de antisemia es el caso del verbo enervar, cuyas dos acepciones en el $D L E$ muestran esta oposición. La propia información etimológica nos ofrece un dato valioso, dado que el Diccionario la hace derivar de ènervāre, con el valor de 'debilitar', entendiendo que el prefijo latino $e(x)$ - aporta el valor negativo, que se representa en la primera acepción, claramente historicista, con lo que sería un sinónimo perfecto de desvitalizar, incluso con el sentido con el que se usa en Odontología (aunque los profesionales prefieran el tecnicismo endodonciar):

1. tr. Debilitar, quitar las fuerzas. U. t. c. prnl.

Sin embargo, si continuamos leyendo, el $D L E$ recoge la otra acepción que, es, precisamente, la que se ha impuesto en el español actual:

3. tr. Poner nervioso. U. t. c. prnl.

Que significa exactamente lo contrario de lo anterior, debido a que cada uno de los valores reseñados procede de dos fuentes diferentes: el primero es el tradicional del español y el segundo es un calco del francés, donde énerver, ya desde siglos (el denominado francés medio) tiene el valor que hemos importado, por la sencilla razón de que el prefijo $e-$ fue interpretado como un enfático en-

Otro caso similar es el de archivo, voz que en español ha encontrado un pariente semántico del inglés con el que convive, pero que ha traído al español un significado no solo diferente, sino, en muchos contextos, opuestos.

La primera acepción en el $D L E$, la heredada del latín archīvum y esta de griego à $\rho \chi \varepsilon i ̃ o v$, es transparente y la clave se encentra en el hiperónimo de la primera palabra de la definición: "Conjunto ordenado de documentos que una persona, una sociedad, una institución, etc., producen en el ejercicio de sus funciones o actividades". Sin embargo, la informática traducida del inglés nos ha traído un mal calco semántico de la voz inglesa file que los técnicos han traducido también como archivo, de tal manera que ahora nos encontramos con que este término se ha convertido en antisémico al valer para un conjunto de documentos y un solo documento al mismo tiempo.

Así, si nuestro ordenador nos muestra alguna de estas frases

"This file is no longer available"

O

“This file can't be used to create an OS X installation disk", 
y su traducción es archivo, estaremos ante la disyuntiva de si el problema afecta a un documento o a un grupo de ellos. Para terminar de complicar el asunto, el Diccionario, en su acepción $n^{\circ} 5$ afirma lo siguiente de la voz archivo:

5. m. Inform. Conjunto de datos almacenados en la memoria de una computadora u otro dispositivo electrónico, que puede manejarse con una instrucción única.

Con lo que file, en su mala traducción, también debe entenderse como "conjunto de datos", que dista mucho de ser lo que el usuario entiende cuando, sencillamente, quiere abrir un documento y este 'ya no se encuentra disponible'.

Un tercer caso nos lo proporciona también el inglés con la voz ignorar, en el que se mezclan los significados de "No saber algo o no tener noticia de ello" y de "No hacer caso de algo o de alguien, o tratarlos como si no merecieran atención", las acepciones 1 y 2, respectivamente. Es cierto que comparten cierto grado de proximidad semántica, pero no lo es menos que desconocer un hecho se opone radicalmente a conocerlo y no tenerlo en cuenta, por lo que, es muy fácil imaginar cientos de contextos en los que un acusado de un delito, por ejemplo, pueda ver alterado sensiblemente su futuro inmediato por la interpretación que de este verbo haga un juez o un jurado, en términos de ignorancia, connivencia, negligencia, etc.

También aquí, como veríamos en el caso anterior, el $D L E$ viene a añadir otra dificultad al asunto, porque, si bien ignorar está afectado de esa antisemia exógena, parece que el adjetivo todavía no ha llegado a ser considerado tal porque solo se recogen dos acepciones que se refieren al hecho de "no saber", sin rastro del de "no hacer caso":

1. adj. Que ignora o desconoce algo.

2. adj. Que carece de cultura o conocimientos. Apl. a pers., u. t. c. s.

Es decir, una oración como *Miguel es ignorante de que María está en la fiesta sería agramatical, pero no estaría intoxicada por la antisemia, al contrario que si se formula de la siguiente manera: Miguel ignora que María está lesté en la fiesta.

\subsection{Antisemia por causas endógenas}

Como parece fácil deducir, consideramos estos tipos de antisemia los producidos por evolución interna del español, a lo largo de su historia, bien por evolución de los significantes, bien por la de sus significados, por su caracterización sintáctica, por variación diatópica y, por último, por variación diafásica o intencional.

\subsubsection{Por evolución morfológica o del significante}

Pertenecen a este apartado los casos en los que dos significantes clásicos, cultos o semicultos, terminan identificándose morfológicamente, pero manteniendo sus significados, que llegan a ser opuestos per se o contextuales.

Aunque los ejemplos son muchos, citemos solamente cuatro, como son los casos de auto, fallar, cenotafio y cenobio o ecografía y ecología.

Cuando encontramos palabras morfológicamente similares, el usuario, el aprendiz o el traductor de nuestra lengua puede llegar a pensar que la presencia del elemento repetido 
es garantía de la reiteración del significado que aporta el elemento compositivo. Así, por ejemplo, dos palabras aparentemente próximas como autodidacta y autoescuela mantienen, en cambio, una relación semántica históricamente, toda vez que el segundo auto-, pese a conservar la carga semántica original de 'propio, por sí mismo', ha adquirido el valor añadido que le ha proporcionado automóvil, de la cual es un mero acortamiento, de tal manera que un receptor poco avezado en el dominio del idioma de nuestra lengua que conozca autodidacta y aplique una falsa analogía a autoescuela, llegará a la falsa conclusión de que se trata de una escuela donde uno aprende por sí mismo.

Complica este asunto en español el hecho de que en otras lenguas no se produce esta confusión morfológica, como observamos en el portugués escola de condução o el italiano scuola (di) guida, hasta en el inglés driving school (y su calco en japonésドライビングスクー ル), o en alemán Fahrschule, con la esperable excepción del francés auto-école (autoécole), si bien en Québec o en Bélgica se prefiere la forma analítica y explícita école de conduite.

Así, en la secuencia María no va a la autoescuela porque es autodidacta, encontramos que el elemento compositivo actualiza dos significados opuestos que enfrenta ambos compuestos, como ocurre, por ejemplo, si observamos un letrero a la puerta de un taller en el que se lea $a u$ totaller, en el que se actualizan el concepto de 'taller para vehículos' (sin referencia a quién se encargue de repararlos) al mismo tiempo que no sabremos si el que debe hacerlo es el propio usuario o no (piénsese en las gasolineras), lo cual puede interpretarse como un 'autoservicio del taller', es decir, 'taller sin personal que atienda a los clientes' o ambos conceptos a la vez.

Un segundo ejemplo lo encontramos en el verbo fallar, procedente de dos étimos totalmente diferenciados en latín, que han llegado a nuestra lengua con el mismo significante, pero con sus respectivas cargas semánticas. Según la Academia, uno de ellos procede de afflare ('soplar', 'olfatear') que derivaría en 'encontrar' y el otro lo hace del latín vulgar falla ('defecto'), algo que produciría una mera polisemia, salvo en casos de antisemia contextual, como ocurre en el siguiente ejemplo: Miguel estaba indignado por el fallo de la comisión.

Un tercer caso, también procedente del griego, como ya explicamos en un trabajo anterior ${ }^{28}$, se observa en el conflicto entre cenotafio y cenobio. En la primera voz, nos encontramos

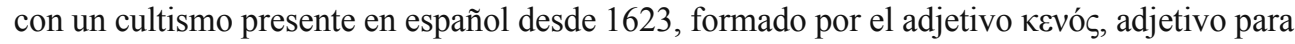
'vacío', y por el sustantivo tọ́́ıov, 'sepulcro' (como en epitafio), llegado a través del latín kenotaphion para designar un 'monumento funerario en el cual no está cadáver del personaje a quien se dedica', según se lee en $D L E$ ( $23^{\text {a }}$ edición), es decir, 'un sepulcro vacío'. Por el contrario, cenobio, documentada en 1236, pese a parecer estar emparentada con la anterior, mantiene con ella una evidente relación de antisemia, toda vez que su origen se encuentra en griego bizantino kovvóßıv (a través del latín tardío coenobŭum, formado por el adjetivo кoเvท́, 'común', como en el tecnicismo lingüístico koiné o coiné, voz ya española que usamos para designar, por ejemplo, esa 'lengua común que resulta de ciertas variedades idiomáticas', según establece el $D L E$ en su segunda acepción. El otro elemento compositivo es bio, es decir, 'vida', presente tanto en biología, biografia o biochip como en decenas de productos alimenticios que han encontrado en este elemento la garantía de ser saludables. Así pues, mientras cenotafio es 'sepulcro vacío', es decir, la negación absoluta de la vida, cenobio hace referencia a la 'vida en común', dado que es un sinónimo de monasterio (voz a la que remite el $D L E$ ), es decir, un espacio habitado por muchas personas, y, por ende, lleno de vida.

28 Torijano (en prensa). 
El último ejemplo que nos muestra este tipo de antisemia lo representan aquellas voces que en español comienzan por el elemento compositivo eco-, aunque, más exactamente, habría que decir por los elementos compositivos eco-, en plural, dado que vuelve a ocurrir como en los dos casos anteriores. En efecto, la presencia en nuestras lenguas de compuestos clásicos como ecografía o economía (o, más recientemente, ecolocalización) con su supuesto parentesco morfológico y semántico es otro motivo de posible error de interpretación y, además, de eventual antisemia contextual, entre otras razones porque existen decenas de compuestos clásicos cuya identidad morfológica corresponde a otra semántica. Así, por ejemplo, en pares como los siguientes: angiografía/angiología, lexicografia/lexicología, litografía/litología, radiografia/radiología, urografia/urología, zoografia/zoología, por nombrar solo algunos, el lexema al que se añaden - grafía y -logía posee siempre la misma carga semántica.

Por el contrario, una somera comparación con lo que ocurre con eco, ecoico, ecolocalización, ecocardiografia o ecosonda frente a ecosistema, economía o ecoturismo, y muy particularmente con ecografia frente a ecología (por continuar con los pares de palabras que veíamos arriba) puede generar un error de interpretación al no ser capaces de diferenciar que en ecología en elemento compositivo procede de oiko 'casa, ambiente', mientras que en ecografía se parte de èchố 'eco'. Esta confusión puede derivar en una antisemia contextual en la eventualidad de tener que generar un neologismo del tipo *ecofobia o *ecoterapia, dado que podrían significar 'horror a estar en casa' y 'horror a salir a la naturaleza' y 'terapia barata, para hacerla en casa' (a partir de economía) o ‘terapia en mitad del campo' (a partir de ecología ${ }^{29}$, respectivamente.

\subsubsection{Por evolución semántica (hiperonimia o imprecisión semántica)}

Este subapartado es el más nutrido y, por ende, el más popular, toda vez que los casos que lo ejemplifican suelen aparecer en secciones de divulgación, "curiosidades del lenguaje", artículos en revistas sobre preguntas de los lectores, etc. Todos ellos son modelos de esta antisemia por evolución del significado, bien porque en algún momento de su cronografía léxica pertenecieron a un nivel semántico superior (grado de hiperónimos), bien porque su grado de precisión semántica no es el suficiente como para evitar la ambigüedad, hasta el punto de poder significar una cosa y la contraria.

Ejemplifican este tipo de antisemia voces como huésped, -da, alquilar, arrendar, huérfano, -na, conjurar, cínico, -ca, sancionar, casero, disculpar, picaporte, prescribir, temeroso, $-s a$, etc., de los que analizaremos las cuatro primeras, aunque es, sin duda, fármaco el protoejemplo señero de esta categoría.

En efecto, como es sabido, fármaco ha servido de ejemplo de este fenómeno desde hace mucho tiempo, toda vez que ya en griego, más concretamente desde Homero (s. VIII

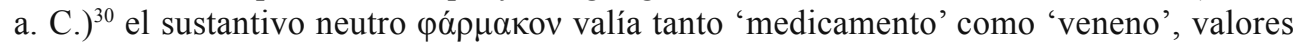
antisémicos que se mantuvieron en el latín tardío pharmăcum ${ }^{31}$, si bien su uso en caste-

29 Es un caso similar al de manufactura frente a manómetro, que nada tiene que ver con mano, sino con el griego $\mu \alpha v o ́ s$, 'raro, escaso', 'poco denso', y se aplica a los gases: 'Instrumento para medir la presión de los fluidos, principalmente de los gases'.

30 DMBHE: s. v. fármaco

31 Concepto plenamente explicitado en la famosa sentencia del médico, alquimista y astrólogo suizo medieval (1493-1541) Theophrastus Philippus Aureolus Bombastus von Hohenheim, más conocido por Paracelso, para quien "Todas las sustancias son venenos, no existe ninguna que no lo sea. La dosis diferencia un veneno de un remedio": "dosis sola facit venenum". 
llano medieval fue poco a poco decantándolo hacia el primero de los significados, único que recoge el diccionario oficial.

De mucha mayor actualidad es el caso de huésped, -da, que reúne no solo la circunstancia de ser uno de los más conocidos, sino, además, la de existir con la misma característica de antisémico en otras lenguas, por el mero hecho de darse ya esta circunstancia en el latín hŏspes, - $\breve{t}$ tis ${ }^{32}$, como ocurre con el italiano ospite, que tanto vale como 'hospedado' y como 'anfitrión', como puede leerse en las acepciones 1. y 3.a que recoge el Dizionario Treccani ${ }^{33}$ :

ospite s. m. e f. [dal lat. hospes -pütis (con tutti e due i sign. fondamentali, in quanto la parola alludeva soprattutto ai reciproci doveri dell'ospitalità)]. - 1. La persona che ospita, che accoglie cioè nella propria casa altre persone (siano queste amici, conoscenti, oppure forestieri, estranei) offrendo loro alloggio e vitto, o anche soltanto per una visita, per una festa, per un ricevimento e $\operatorname{sim}[\ldots .$.

2. estens. e fig. a. In parassitologia e in zoologia, la specie, animale o vegetale, a spese del quale vive un parassita; anche come agg.: l'animale, la pianta ospite.[...]

3. a. Più comunem., la persona ospitata: presso i popoli antichi l'o. era sacro; sono stato suo o. per alcuni giorni; sarei felice di avervi ospiti nella nostra villa; essere o. di una famiglia, di una casa, di un paese; accogliere, intrattenere, congedare gli o. (soprattutto quelli venuti per un ricevimento o sim.) [...].

A este respecto, la propia Accademia della Crusca, la institución que recoge estudios científicos de la filología italiana, y considerada la institución lingüística más prestigiosa de Italia desde su fundación en Florencia en 1583, ratifica que su carácter antisémico no es sino una herencia directa del latín, donde, como decíamos más arriba, ya reunía los dos significados opuestos:

La parola ospite deriva dal latino hospes, -ittis, che aveva già il doppio significato di 'colui che ospita e quindi albergatore' e di 'colui che è ospitato e quindi forestiero', significato -comune alla parola greca xénos- che si è tramandato in quasi tutte le lingue romanze (antico francese (h)oste; francese moderno hôte; occitano e catalano oste; spagnolo huésped; portoghese hóspede). Ed è dunque proprio alla storia della lingua latina che dovremo guardare per rispondere alla curiosità che questa parola suscita ${ }^{34}$.

Del mismo modo, observamos que en francés, como recoge en su página web el Centre National de Ressources Textuelles et Lexicales (CNRTL) ${ }^{35}$, la voz hôte, hôtesse presenta simultáneamente, entre otras, las siguientes acepciones:

A. - Personne qui reçoit (quelqu'un) dans sa demeure ou invite au restaurant, qui offre l'hospitalité. Hôte attentionné, empressé; hôtesse charmante, prévenante; prendre congé de ses hôtes. [...]

32 NDELE: s. v. hŏspes, -ittis

33 Del Instituto Treccani, heredero del prestigioso Instituto Giovanni Treccani, y una de las fuentes lexicográficas más autorizadas de la lengua italiana.

34 Accademia della Crusca: http://www.accademiadellacrusca.it/it/lingua-italiana/consulenza-linguistica/domande-risposte/chi-effettivamente-1-ospite [Consulta: 10 de junio de 2019].

35 Perteneciente al Centre National de la Recherche Scientifique (CNRF): https://www.cnrtl.fr/definition/ h\%C3\%B4te [Consulta: 10 de junio de 2019]. 
B. - Personne qui est accueillie (chez quelqu'un), qui reçoit l'hospitalité. Synon. invité. Hôte illustre, de passage; recevoir des hôtes. [...]

Por su parte, el portugués parece encontrarse en un proceso de disolución de la antisemia, dado que, si bien hóspede recoge también ambos significados antitéticos, parece estar imponiéndose el de 'hospedado':

1. Que ou quem está alojado num estabelecimento hoteleiro.

2. Que ou quem está temporariamente alojado em casa de outrem.

3. Que ou quem está por pouco tempo numa localidade ou região ${ }^{36}$.

Sin embargo, al comprobar la etimología propuesta, el resultado es el siguiente:

(latim hospes, -itis, hóspede, anfitrião),

valor que se mantiene en el verbo hospedar, bajo cuyo lema podemos leer, en la acepción cuarta:

(hóspede $+-a r)$

verbo transitivo

1. Receber em sua casa como hóspede.

2. [Biologia] Ter a função de hospedeiro de (ser parasita).

3. [Informática] Fornecer o equipamento e as condições necessárias para manter um site.

verbo pronominal

4. Estabelecer-se como hóspede. $=$ ALOJAR-SE

En el mismo sentido, el prestigioso Dicionário Aurélio, después de la primera acepción ("Aquele que se aloja temporalmente en casa alheia"), encabeza la segunda con la marca Desus. antes de definirla como "Hospedeiro", donde parece ratificarse ese proceso de liquidación de la antisemia, fenómeno que, como veremos, discurre paralelo a lo que ocurre en español.

En efecto, en el caso del $D L E$, entre la dudosa duplicidad de acepciones, es evidente la antisemia entre los valores de 1 y 2 , frente a los de 3,4 y 5 :

\section{huésped, da}

Del lat. hospes, - ittis.

Para el f., u. m. la forma huésped en aceps. 1 y 2.

1. $\mathrm{m}$. y f. Persona alojada en casa ajena.

2. m. y f. Persona alojada en un establecimiento de hostelería.

3. m. y f. p. us. Mesonero o amo de posada.

4. m. y f. p. us. Persona que hospeda en su casa a otra.

5. m. Biol. Vegetal o animal en cuyo cuerpo se aloja un parásito.

Sin embargo, y como ocurría con el portugués, una marca de uso nos advierte de su uso minoritario, algo que la Academia ya venía proponiendo desde 2005 en el Diccionario panhispánico de dudas bajo la voz que nos ocupa:

36 Dicionário Priberam da Língua Portuguesa [em linha]: https://dicionario.priberam.org/hospede 2008-2013, [Consulta: 10 de junio de 2019]. 
[...] Fuera de este ámbito [el de la biología], es preferible hoy reservar el término huésped para designar a quien recibe alojamiento, y denominar anfitrión al que lo proporciona.

En el mismo ámbito semántico, es conocida la antisemia del verbo alquilar (y del sustantivo correspondiente), sin que haya la más mínima apoyatura léxica que ayude al traductor, al estudiante de español o al propio usuario nativo de nuestra lengua a discernir si debe optar por un significado u otro, evidentemente antisémicos:

\section{alquilar}

De alquilé.

1. tr. Dar a alguien algo, especialmente una finca urbana, un animal o un mueble, para que use de ello por el tiempo que se determine y mediante el pago de la cantidad convenida.

2. tr. Tomar de alguien algo para usarlo por el tiempo y precio convenidos.

3. prnl. Dicho de una persona: Ponerse a servir a otra por cierto estipendio.

Problema que se agrava en el caso de arrendar, cuyos dos significados opuestos aparecen en la misma acepción, lo que dificulta aún más el problema:

\section{arrendar $^{1}$}

De renda 'renta'.

1. tr. Ceder o adquirir ${ }^{37}$ por precio el goce o aprovechamiento temporal de cosas, obras o servicios.

Fenómeno idéntico al que encontramos en su traducción al portugués con el verbo alugar:

a·lu·gar (latim medieval alloco, -are)

verbo transitivo

1. Dar ou tomar de aluguer.

2. Arrendar.

3. Assalariar.

4. [Brasil, Informal] Ocupar o tempo de alguém ${ }^{38}$.

En este mismo sentido, comprobamos que en una lengua no latina como el inglés, el fenómeno se repite con el verbo to rent, que significa tanto 'dar' como 'tomar' algo en alquiler, sin que haya elementos morfosintácticos que disuelvan el problema, salvo, quizá, algún sintagma preposicional que dirija la acción hacia el dador o hacia el tomador.

Sin embargo, en alemán la solución que han encontrado es sencilla, pese a que la situación era la misma: el verbo mieten, en origen exactamente igual de antisémico que los equivalentes que estamos analizando, adopta el prefijo inseparable ver-, uno de los más productivos en alemán, que aporta valores tan variados como 'erróneo, equivocado', 'contrario, opuesto' ${ }^{39}$, 'totalmente, hasta el final', 'mucho más o demasiado', 'unir', 'cubrir con algo,

37 La única salvedad que concede la Academia es la diferencia entre arrendatario, -ria (1. adj. Que toma en arrendamiento algo.) y arrendador, -ora (1. m. y f. Persona que da en arrendamiento un bien.), lo cual supone una pequeña ayuda a la hora de entenderlo, aprenderlo o traducirlo.

38 Dicionário Priberam da Língua Portuguesa [em linha], 2008-2013, https://dicionario.priberam.org/alugar [consultado em 18-06-2019].

39 Este valor de opuestos se observa perfectamente en pares de verbos como lo siguientes: blühen ('florecer') frente a verblühen ('marchitarse') o achten ('estimar, apreciar') frente a verachten ('despreciar'). 
añadir, decorar', o 'hacia fuera', por citar algunos, para diferenciar perfectamente los dos significados ante la situación de que alguien quiera alquilar un piso:

Valor 'tomar' (arredantario): Ich möchte eine Wohnung mieten.

Valor 'dar' (arrendador): Ich möchte eine Wohnung vermieten.

Como se aprecia en la oposición de los verbos kaufen y verkaufen, respectivamente, 'comprar' y 'vender', solución que convive con opciones sintácticas más complejas, pero igualmente válidas, como ocurre con los verbos leihen y ausleihen ('prestar' y 'pedir prestado', respectivamente), que rigen diferentes pronombres átonos, según sea la dirección del préstamo:

Valor 'prestar' (prestador): Ich leihe dir $10 €$.

Valor 'pedir prestado' (prestatario): Ich leihe mir $10 €$ aus.

A este respecto, es significativo comprobar cómo en algunas zonas del inglés de Estados Unidos, por ejemplo, en el medio oeste ${ }^{40}$, los valores de 'prestar' y 'pedir prestado', que en inglés estándar sí exigen verbos diferenciados (to lend y to borrow, respectivamente) se funden en una única forma antisémica, to borrow:

Valor 'prestar' (prestador): My father borrows me the car ('mi padre me presta el coche') Valor 'pedir prestado' (prestatario): My father borrows my car ('mi padre me pide prestado el coche')

Concluimos este subapartado con un ejemplo que pone de manifiesto la necesidad, no solo lingüística, sino también social de solventar por alguna vía la cuestión de la antisemia. Nos referimos al caso de huérfano, -na, cuya presencia en el $D L E$ revela rápidamente el problema en acepciones tan seguidas como la 1 y la 2 :

Del lat. tardío orphănus, y este del gr. ỏppavós orphanós.

1. adj. Dicho de una persona menor de edad: A quien se le han muerto el padre y la madre o uno de los dos. U. t. c. s.

2. adj. poét. Dicho de una persona: A quien se le han muerto los hijos.

3. adj. Falto de algo, y especialmente de amparo. En aquella ocasión quedó huérfana la ciudad.

4. adj. desus. expósito. U. en Bol. y Chile.

Como se observa, después del contorno semántico de ambas acepciones, la misma voz puede aplicarse a quien ha perdido a los padres como a quien se le han muerto los hijos, lo cual no es precisamente un modelo precisión léxica, pese a que el Diccionario aporte la marca "poét.", que puede lenificar el problema.

La inclusión de esta voz en este epígrafe, referido a antisemia por hiperonimia o imprecisión semántica, responde al hecho de que, pese a que, en efecto, orphănus hace su aparición en el latín tardío, en realidad procede del clásico orbus, con el valor ya entonces de 'privado de [un miembro de: padre, madre, hijo...]', de modo podemos encontrar locuciones tanto del

40 Agradecemos al profesor Dr. Daniel Linder la precisión en la extensión de este fenómeno. 
tipo orbus senex, es decir, 'anciano sin hijos' como filii orbi 'hijos huérfanos' u orbus auxiliis, 'privado de auxilios'. Se trata, pues, de una hiperonimia que se ha mantenido a lo largo de los siglos hasta nuestros días, lo cual ha creado la necesidad social de llevar, por ejemplo, a que en octubre del 2017, la Federación Española de Padres de Niños con Cáncer ${ }^{41}$ propusiera a la Real Academia Española la inclusión en el Diccionario del término huérfilo, -la, para "representar a todos aquellos padres que han sobrevivido al fallecimiento de un hijo".

\subsubsection{Sintáctica: antisemia producida por la presencia o ausencia de pronombres átonos}

Constituyen este grupo de voces antisémicas aquellas en las que el fenómeno se produce por la presencia o ausencia de los pronombres átonos, cuyo aprendizaje y dominio suele acarrear severos problemas e interminables horas de atención y estudio a quienes no tienen nuestra lengua como materna, incluyendo a hablantes de lenguas tan aparentemente próximas como portugués o el italiano.

Es igualmente sabida la dificultad de muchos profesores para enseñar, incluso a escolares hispanohablantes, eso que se denomina "los valores de $s e$ ", tanto desde el punto de vista sintáctico como el del semántico, si bien este último aspecto suele resolverse de forma intuitiva entre los hablantes nativos, pero no ocurre lo mismo entre los estudiantes de español como segunda lengua o entre los aspirantes a traductores. Y es precisamente este déficit semántico el que se manifiesta de diversas formas entre las que se encuentra la dificultad de discernir entre el valor $\mathrm{A}$ y el $\mathrm{B}$ de un mismo verbo, según vaya acompañado o no del pronombre átono.

Observemos ahora algunos de los incontables ejemplos posibles, muchos de los cuales apenas necesitan más comentario que las propias frases que les sirven de contexto, y que representan unidades de discurso perfectamente posibles en los que la antisemia dificulta la comprensión de las secuencias. Veremos ejemplos de los verbos pasar(se), salir(se), dormir(se), hacerse(se) pis y dar(se).

Como constatábamos más arriba (2.2. La antisemia no es polisemia), el $D L E$ recoge un total de $\mathbf{6 4}$ acepciones y $\mathbf{1 4}$ locuciones y expresiones del verbo pasar, un verdadero alarde de polisemia en el que no es imposible encontrar casos de antisemia, especialmente si, como decimos, las formas aparecen o no con pronombre átono, cuya función teórica sería recibir la acción del verbo.

Este puede ser el caso del siguiente microdiálogo, perfectamente extraíble de millones de conversaciones diarias que pueden producirse entre dos hispanohablantes:

- ¿Qué te pasa, hombre?

- Me pasa que me duele la cabeza y no se me $\operatorname{pasa}^{42}$.

Donde el primer valor sería 'ocurrir, acontecer', mientras que el segundo sería 'dejar de ocurrir, de acontecer'.

O en oraciones como Cuando era joven, (le) pasaba de todo, en la que, según aparezca o no el pronombre, el joven se veía inmerso en muchas vicisitudes y acontecimientos o, por

41 Nace una palabra: https://cancerinfantil.org/2017/10/10/nace-una-palabra-denominar-todos-aquellos-padresperdido-hijo-huerfilos/

42 En muchas zonas del noroeste español, cuyos paradigmas pronominales difieren de los considerados estándares, puede encontrarse, incluso, como "- Me pasa que me duele la cabeza y no me pasa". 
el contrario, hacía todo lo posible por no inmiscuirse en nada de lo que pudiera rodearlo, o, en palabras del $D L E$, era "Indiferente ante las cuestiones que importan o se debaten en la vida social" $" 43$.

Y, del mismo modo, si observamos el siguiente ejemplo con el verbo salir(se) y pensamos en un aprendiz de nuestra lengua o en un traductor/intérprete no demasiado avezado, descubriremos que el mero pronombre es capaz de generar un sentido o su contrario:

- ¿Qué tal la película de ayer, salisteis muy tarde?

- No sé, yo me salí.

Donde el primer valor solo se refiere a la hora de finalización de la proyección, mientras que el segundo aporta una información que pasaría desapercibida a esos aprendices porque el pronombre aporta un valor totalmente diferente: el sujeto está diciéndonos que la película no le gustó, que tuvo que salir antes de que terminara, etc., sin que, aparentemente, haya ningún elemento temporal que así lo indique.

De idiosincrasia similar es lo que ocurre con el verbo dormir(se), en el que el pronombre añade el valor (además del de 'quedarse dormido'44) de 'dormir donde/cuando no es habitual', prácticamente imposible de detectar sin un conocimiento profundo de nuestra lengua, como podemos leer en el siguiente ejemplo:

El abuelo se duerme a todas horas porque no duerme bien.

Y también sucede con hacer(se) pis/caca, donde la presencia del reflexivo transforma por completo el sentido y puede generar esa antisemia contextual que estamos analizando:

- ¿El niño ya no se hace pis?

- No, ya hace pis como una personita mayor.

Como en el caso anterior, el pronombre añade un valor de anomalía ${ }^{45}$, en este caso, 'hacerse pis encima' sin que sea necesaria la presencia del adverbio, lo cual genera un contrasentido, porque el niño no se hace pis pero hace pis.

Terminamos esta pequeña muestra de ejemplos con el caso del verbo dar(se), casi tan polisémico como pasar y, por tanto, altamente susceptible de alojar antisemias en su uso, especialmente en registros coloquiales. Si nuestros aprendices de español o estudiantes de traducción se encuentran con un diálogo como el siguiente, entre dos personas de distinto tamaño que hablan sobre la ropa:

- ¿Me dejas ese jersey?

- No, que me lo das.

En este caso, el campo semántico de dar, en el que se incluye dejar como 'dar por un tiempo', estaría condicionando la interpretación del verbo de la segunda oración hasta el punto

43 DLE: s. v. pasota.

44 El que hace diferenciar El domingo me dormí a las 9 de El domingo dormí 9 horas, sin que puedan intercambiarse.

45 Además del de 'querer hacer pis'. 
de que parecería que el posible dejador del jersey pasa a ser la otra persona, que, de repente, se convertiría en dador de la prenda, en un evidente caso de contrasentido contextual, agravado por la ausencia del complemento de sí, si bien cabe reconocer que en niveles no demasiado elevados de dominio lingüístico tampoco aportaría demasiada información como para comprender que estamos modificando la locución verbal que la Academia ${ }^{46}$ define como 'extenderse, ensancharse', tanto la ropa como el suelo o la inteligencia.

\subsubsection{Dialectal: antisemia por variación diatópica}

La evidente fragmentación lingüística de nuestra lengua ${ }^{47}$, especialmente en registros coloquiales, parece propiciar una consecuente diversificación de significados por polisemia. Piénsese que, además de la veintena de países generadores de sus propios significados para significantes comunes, el DLE recoge un total de 57 marcas lexicográficas más, correspondientes a provincias y regiones españolas y americanas, entre las que se reconocen, por ejemplo, las áreas de los Andes, del Caribe, guaranítica, América Central, América Meridional, el Levante español o La Mancha, lo que propicia un prácticamente infinito abanico de significados dobles, triples o más para un mismo significante. Como afirma M. ${ }^{a}$ L. Regueiro (2010: 34):

La polisemia dialectal puede llevar a ciertas confusiones en las sinonimias, si no se diferencian adecuadamente las acepciones y sus respectivas regiones de uso.

Idea ratificada y ampliada cuatro años más tarde, referida a las entradas simples y a las unidades fraseológicas, por P. Mogorrón (2014:128)

$\mathrm{Si}$ en todas las lenguas aparecen variantes regionales, en el caso de lenguas como el español, el francés, el inglés, etc. que son hablados en numerosos países por decenas y/o centenas de millones de personas, existen a su vez numerosísimas creaciones idiosincrásicas propias a cada país, cada cultura y a sus referentes culturales. Se trata de las expresiones o de las variantes utilizadas en los diferentes países en los que estas lenguas son lenguas oficiales y son habladas por gran parte de su población. Estas UF son creaciones propias a cada uno de estos países cuyo(s) significado(s) a menudo a pesar de tener componentes léxicos del español resultan opacos para los usuarios españoles debido en gran medida a que no pertenecen a la competencia fraseológica de los usuarios españoles.

$\mathrm{Y}$, como hemos visto repetidamente, la polisemia es un excelente caldo de cultivo para la antisemia, dado que es de ella de donde nace.

Pese a que los ejemplos son innumerables, centraremos este apartado en tres voces muy significativas que ilustran sobradamente el problema.

El primer caso lo encontramos en el adverbio luego, al que el $D L E$, en esta categoría, le concede cuatro acepciones, la primera de las cuales, hasta la edición digital de 2018, era

46 DLE: s. v. dar.

47 Según el informe anual del Instituto Cervantes "El español en el mundo 2018”, 577 millones de personas hablan español en una veintena larga de países, lo que representa el 7,6\% de la población mundial de hablantes, de los cuales 480 millones lo tienen como lengua materna: https://www.cervantes.es/sobre_instituto_cervantes/ prensa/2018/noticias/np_presentacion-anuario.htm. 
"Prontamente, sin dilación"48, por encima de la siguiente, que reza "Después, más tarde.", lo cual ya representa un contrasentido, especialmente en el ámbito pragmático de una respuesta a una orden o a una petición.

Debemos añadir inmediatamente que esa posición preeminente en la entrada en el diccionario no es, en absoluto, extraña a lenguas próximas como el portugués ${ }^{49} \mathrm{o}$ el gallego ${ }^{50}$, dado que su equivalente logo conserva el valor latino de 'tiempo inmediato', y todo parece indicar que incluso en español estándar, donde la expresión de saludo/despedida ;hasta luego! se aproxima semánticamente más a jhasta ahora! o a ¡hasta pronto!, que a un supuesto ¡hasta después!, como para manifestar un deseo de volver a verse cuanto antes, como, por otra parte, se mantiene en la inglesa See you soon. Y no solamente en lexicalizaciones formularias como los saludos, sino también en el uso cotidiano de algunas zonas del noroeste español, donde es frecuente encontrar secuencias, por ejemplo, en boca de los padres, y quizá más frecuentemente de las madres, diciéndoles a sus hijos cuando estos se disponen a salir por la noche:

¡Ven luego, que sabes que no me duermo hasta que no vienes!

Un segundo caso nos lo proporciona el verbo aprender, definido por el Diccionario como "adquirir el conocimiento de algo [...]", pero también como "Enseñar, transmitir unos conocimientos", marcada, esta quinta y última acepción, como desusada. Sin embargo, y quizá como un ejemplo más de la necesidad de revisar el sistema de marcas del $D L E$, hay muchas zonas del español peninsular donde continúa usándose con plena vigencia, especialmente en registros coloquiales.

Así, por ejemplo, en algunas partes de Asturias, un niño puede decir:

Hoy la maestra nos aprendió los colores del arcoíris.

Del mismo modo que en la galardonada película Carmen y Lola, dirigida por Arantxa Echevarría y estrenada y ambientada en 2018 (lo cual no parece responder al concepto de "desus." del Diccionario), una madre habla con una de las protagonistas para recordarle lo que ella le ha enseñado:

- MADRE DE CARMEN: Mira, ven para aquí, que quiero hablar contigo. [...] Que a mí no me tengan que venir a poner la cara colorá, a llamarme la atención porque tú no sepas ser una mujer de tu casa. Porque yo te he aprendido a ser una gitana de tu casa y a ser una mujer. [...] Así que venga, tira ya.

El tercer y último ejemplo de este apartado nos lo proporciona el verbo aguantar, en el que se reúnen, entre otros, los valores antisémicos de 'resistir, soportar' y de 'apurarse, darse prisa" ${ }^{\prime \prime}$, significados que entran en conflicto en muchos contextos habituales, espacialmen-

48 En la última versión digital de mayo de 2019, esta acepción ha sido relegada a la cuarta posición, con la marca "desus." y la información de que se usa más en América.

49 Wordreference: $\operatorname{logo}: 1$. (imediatamente) ya:

Ej.: "Disse ao médico que venha logo pois está muito grave" ("Le he dicho al médico que venga ya, que está muy grave".)

50 DRAG: s. v. logo. 1. En pouco tempo, sen tardar. [...] SINÓNIMOS axiña, decontado, deseguida, enseguida, rápido / 2. Máis tarde no tempo. [...]. SINÓNIMO despois.

51 El $D L E$ sitúa en la acepción $10^{\text {a }}$ esta definición: "Adelantar en el trabajo". 
te en algunas partes dialectales del español, y no solo en el peninsular, sino también en el atlántico, toda vez que, frente a la idea de "darse prisa", en Ecuador significa "Retardar deliberadamente la marcha de un vehículo de servicio público para recoger en el trayecto mayor número de pasajeros”, lo que viene a complicar aún más la antisemia.

Como ejemplo de las dos primeras acepciones citadas, podemos observar este microdiálogo, recogido en una población cercana a Galicia:

- Tengo que ir al cuarto de baño.

- Pues aguanta, que yo también quiero ir.

Muestra perfecta de antisemia, dado que el verbo podría interpretarse con el valor más estandarizado de 'resiste, espera', cuando lo que realmente significa es 'date prisa, que yo también quiero entrar (después de ti)', significado casi seguro imposible de comprenderse y/o traducirse sin un dominio profundo de la situación comunicativa.

\subsubsection{Intencional: usos irónicos, figurados, poéticos...}

El último epígrafe de nuestra propuesta de clasificación de los tipos de antisemia corresponde a los casos en los que el uso de la lengua ha generado valores opuestos a los canónicos, con la agravante de la coexistencia de ambos en el léxico pasivo y activo de los hablantes. Bien es cierto que, como es sabido, el contexto suele aportar las herramientas suficientes para la selección semántica, aunque esto no siempre ocurre y no para todos los elementos de un acto comunicativo.

Así, por ejemplo, no entraría en este apartado una voz como menudo, -da por razones que explicamos a continuación. Si en una receta de arroz con bogavante, por ejemplo, encontramos la secuencia "trocear muy menudo el tomate", no habrá demasiado problema en comprender y traducir su significado recto. Incluso si, comentando el plato, un hablante exclama: “Menudo arroz con bogavante nos comimos ayer!”, la posición, la modalidad oracional y hasta la entonación o los signos de exclamación serán esas herramientas que eviten que la simple polisemia dificulte la correcta interpretación de cada secuencia, y ello a pesar de que la Academia, debajo de acepciones referidas a "pequeño tamaño", "persona pequeña y delgada", "despreciable" o "plebeyo"

6. adj. Seguido de un nombre, u. para enfatizar el significado de este. ;Menudo enredo!

Donde, nuevamente, las marcas de uso brillan por su ausencia ${ }^{53}$ y se obligue al lector a adivinar el salto semántico entre las cuatro primeras acepciones, todas ellas pertenecientes al campo de lo pequeño, y la quinta, en la que la palabra clave es "enfatizar".

En cambio, sí forman parte del grupo de voces susceptibles de producir antisemia intencional algunas como valiente, figura o lumbrera(s), por citar solo algunos ejemplos.

El primer caso, aunque no es exactamente igual que menudo, -da, comparte algunas características con él, dado que también puede aparecer en secuencias del tipo El chico

52 DLE: s. v. menudo.

53 Pese a que, con criterios internos, sí concede la marca "peyor." A un total de 160 entradas, entre las que figuran amasar, caso, encasillar, especular, mercader, orquestar, perro o ratón, por ejemplo. 
aquel fue muy valiente enfrentándose a los ladrones, al lado de expresiones negativas como ¡Valiente desgraciado! o ;Valiente sinvergüenza está hecho ese! Sin embargo, en este caso contamos con la ventaja de que el $D L E$ sí considera oportuno explicar la quinta acepción con la marca de ironía, aunque, como se observa, el significado que aporta difiere bastante del de los hablantes, lo cual no parece concordar con el sentido que se le pretende dar:

5. adj. Grande y excesivo. U. m. en sent. irón. ;Valiente amigo tienes! $!^{54}$

Muy diferente es el caso figura, que reúne 23 entradas simples y más de una quincena de entradas compuestas y locuciones, dado que duplica la información en las acepciones 22 y 23: la primera para remitirnos a figurón (\| persona fantasiosa y engreída) y la segunda, en el sentido marcado como coloquial, propio de España y usado mayoritariamente como irónico, ejemplificada de este modo: El tío es un figura que quiere hacerse famoso como sea.

Sin embargo, si analizamos detenidamente el ejemplo, observamos la presencia del artículo indeterminado, perfectamente asumible por el hablante nativo, pero no así para el aprendiz de español o para el aspirante a traductor, dado que plantea dos problemas, no explicados ni marcados en absoluto por el Diccionario.

Por una parte, y como ocurre con otros muchos adjetivos usados negativamente en español, figura aparece precedido por el artículo para enfatizar ese valor, como vemos en eres imbécil leres un imbécil, eres gilipollas/eres un gilipollas, eres vago/eres un vago, fenómeno que no ocurre con adjetivos positivos: eres elegante y no *eres un elegante, eres inteligente pero no *eres un inteligente, eres generoso pero no *eres un generoso (frente a, por ejemplo, eres un tacaño).

Y por otra, la coloquialidad de la expresión parece producir una aparente discordancia de género, al anteceder un a figura, por mucho que el Diccionario use las marcas gramaticales "m. y f." para el uso que nos ocupa. Este recurso, igualmente propio del lenguaje coloquial, como en un cabeza loca, un cabeza de chorlito, un bocachancla, un jeta o un piernas (con la aparente añadida discordancia de número), es igualmente fuente previsible de problemas para los no nativos, que pueden no asimilar la antisemia contextual que opone secuencias como las siguientes: ser una figura del toreo frente ser un figura y estar siempre sin oficio ni beneficio.

El último de los ejemplos, lumbrera(s), reúne igualmente dos elementos de dificultad: por un lado, y como ya parece ser costumbre, el Diccionario no ofrece ninguna marca de uso (ni peyorativo ni irónico) que ayude a discernir la antisemia del elogio (3. f. Persona que brilla por su inteligencia y conocimientos excepcionales) frente al vituperio irónico, con lo que ello puede suponer a un lector o a un traductor no muy avezado.

$\mathrm{Y}$ por otro, nos encontramos ante un ejemplo perfecto de lo que nosotros denominamos plural connotativo, presente en muchos nombres de partes del cuerpo que modifican morfológicamente su número para connotar negatividad respecto a dicha parte o a alguna actividad o acción referida a ella. Recuérdense ejemplos como las barbas, los bigotes, los pelos, las espaldas, las narices, los morros, las pintas, las mientes, las entendederas, etc., muchos de ellos presentes en unidades fraseológicas, en dichos populares, etc. En nuestro ejemplo, es evidente que ser un lumbreras (como ocurría con un piernas) reúne la aparente discordancia de género que comentábamos antes y la de número, opción impensable para el 
valor recto de la voz que nos ocupa, pero susceptible de generar errores de comprensión y/o traducción, y hasta de producción, si el hablante no nativo repite de manera poco analítica lo que pueda oír o leer a hablantes nativos.

\section{A MODO DE CONCLUSIÓN}

A lo largo de este trabajo, hemos pretendido describir y analizar el fenómeno semántico de la antisemia y de demostrar que se trata de un proceso que, si bien es común a otras lenguas, está profundamente arraigado en la esencia más profunda del español, el denominado "ADN de la lengua", lo que genera mayores problemas a la hora de su comprensión, aprendizaje y traducción.

Igualmente, hemos aportado argumentos de diversa índole, basados en datos objetivos, para simplificar las peculiares denominaciones de enantiosemia y autoantónimos por las más sencillas, coherentes y sistemáticas de antisemia y antisémicos, al tiempo que hemos establecido una categorización rigurosa de los diferentes tipos de este fenómeno semántico que no se había planteado con anterioridad.

Por su parte, hemos comprobado cómo esas diferentes clases de antisemia revelan la expansión y profundidad del fenómeno, que afecta todos los registros sociolingüísticos, todas las fases diacrónicas y todas las situaciones diafásicas, lo que nos ha llevado a poner de manifiesto algo que era perfectamente previsible, pero que precisaba de un análisis profundo: la antisemia puede ser causante de muchos errores de interpretación y producción porque el dominio de los valores semánticos de estos significantes de doble valor antagónico (bien por razones de la idiosincrasia de la voz, bien por motivaciones generadas por el contexto) exige un conocimiento muy profundo de la lengua o lenguas de que se trate.

Y, como consecuencia de esa situación descrita y ejemplificada por extenso, pretendemos llamar la atención sobre el hecho de que es imprescindible que las obras de referencia, de consulta, las memorias de traducción y otras herramientas determinen con precisión científica y didáctica los condicionantes semánticos y, sobre todo, pragmáticos, tanto para la comprensión del discurso (sea en la propia lengua o en otra) como para la producción de uno nuevo (igualmente, en una lengua propia o no).

\section{REFERENCIAS BIBLIOGRÁFICAS}

Aquino, T. de (1994). Suma teológica (16 vol.), Madrid: Biblioteca de Autores Cristianos, vol. I, pp. 107-113.

Beccaria, G. L. (ed.) (2004). Dizionario di linguistica. Turín: Einaudi.

Belmar Bizama, L. (2006). "La denominación como proceso semántico en una historieta chilena", Contextos, estudios de humanidades y ciencias sociales, $\mathrm{N}^{\circ} 15$, Santiago de Chile, pp: 55-68.

BICC $=($ Revista) Boletín del Instituto Caro y Cuervo. Instituto "Caro y Cuervo" (1964). Bogotá (Colombia). THESAURUS. Tomo XIX. Núm. 1 Revista de Dialectología y Tradiciones Populares, vols. XVIII y XIX: https://cvc.cervantes.es/lengua/thesaurus/pdf/19/TH_19_003_204_0.pdf y http://thesaurus.caroycuervo.gov.co/index.php/thesaurus/article/viewFile/390/370

Cárdenas Maragaño, B. (2015). "Los apodos: individualizadores conceptuados", Osorno (Chile): Alpha 41 Universidad de Los Lagos.

Carlucci, L. / Díaz Ferrero, A. M. a (2007). "Falsas equivalencias en la traducción de lenguas afines: Propuesta taxonómica", Sendebar: Revista de la Facultad de Traducción e Interpretación, ISSN 1130-5509, no. 18, págs. 159-190. 
Casas Gómez, M. / Muñoz Núñez, M. D. (1992): "La polisemia y la homonimia en el marco de las relaciones léxicas”, en Wotjak, Gerd (ed.): Estudios de lexicología y metalexicografía del español actual. 47. Lexicographica Series Maior. Tübingen: Niemeyer, pávarogs. 134-58.

Casas Gómez, M. / Hummel, M. (2017): "Limitaciones y nuevos retos de la semántica léxica”, RILCE 33.3, págs. 869-911.

Castilla del Pino, C. (1972). Introducción a la hermenéutica del lenguaje. Barcelona: Península, (2a ed. $1974 ; 3^{\mathrm{a}}$ ed. 1975).

DABLP = Ferreira Buarque de Holanda, A. (1999). Dicionário Aurélio Básico da Língua Portuguesa. $3^{\mathrm{a}}$ ed. Rio de Janeiro: Nova Fronteira.

DCECH = Corominas, J. / Pascual, J. A. (1991-1997). Diccionario crítico etimológico castellano e hispánico. Obra completa. Madrid: Gredos, (4) 51-53.

$D E A=$ Seco, Manuel/Andrés, Olimpia/Ramos, Gabino (1999). Diccionario del español actual. Madrid: Aguilar.

$D L E=$ Real Academia Española y Asociación de Academias Americanas: Diccionario de la Lengua Española. [En línea] <dle.rae.es> (06-06-2020).

$D L M=$ Alcaraz Varó, E. / Martínez-Linares, M. ${ }^{\mathrm{a}}$ A. (2004). Diccionario de lingüística moderna . Barcelona: Ariel. $2^{\mathrm{a}}$ ed.

$D M B H E=$ Cortés Gabaudan, F. (coord.): Diccionario médico-biológico, histórico y etimológico de la Universidad de Salamanca. Dicciomed.eusal.es [en línea] < dirección web> (07-06-2020).

$D P D=$ Real Academia Española y Asociación de Academias de la Lengua Española (2005). Diccionario Panhispánico de Dudas. Madrid: Santillana.

DPLP = Dicionário Priberam da Língua Portuguesa [em linha], 2008-2013, https://dicionario. priberam.org/alugar (10-06-2020).

$D R A G=$ Real Academia Galega: Dicionario da Real Academia Galega [em línea]: https://academia. gal/dicionario (11-06-2020).

DTF = Lázaro Carreter, F. (2008). Diccionario de términos filológicos. Madrid: Gredos, Nueva Biblioteca Románica Hispánica,

Eulenberg, A.: "Words that are their own opposites", Linguist List 6.74, Fri 20 Jan 1995, SUM: Words that are their own opposites, pt. 1

Federación Española de Niños con Cáncer: https://cancerinfantil.org/2017/10/10/nace-una-palabradenominar-todos-aquellos-padres-perdido-hijo-huerfilos/

Fundación del Español Urgente de la Agencia EFE (Fundéu). Compendio ilustrado y azaroso de todo lo que siempre quiso saber sobre la lengua castellana. Madrid: Debate, 2016. Artgerust.com.

Herring, J.: Word Study, 37, Merriam-Webster's Magazine, W1962, pág. 8.

Lederer, R. (1998). Crazy English. The Ultimate Joy Ride Through our Language, Nueva York: Revised edition, PocketBooks, pp. 86-95.

Lingoda: "Los verbos reflexivos y los verbos de cambio": https:/www.lingoda.com/en/media/ download/6406

Mogorrón Huerta, P. (2014). "Importancia (numérica) de las variantes diatópicas españolas y su tratamiento en los diccionarios". Yearbook of Phraseology 5. 123-144. DOI 10.1515/ phras-2014-0006. De Gruyter: https://www.degruyter.com/view/j/yop.2014.5.../phras-2014-0006/ phras-2014-0006.xml (13-06-2020)

NDELE = Segura Munguía, S. (2001). Nuevo diccionario etimológico latino-español y de las voces derivadas. Bilbao: Universidad de Deusto.

Organización Mundial de la Salud (OMS), CIE 11 (2018). Trastornos mentales y del comportamiento: descripciones clínicas y pautas para el diagnóstico. Ginebra: World Health Organization: http:// www.who.int/iris/handle/10665/37958.

Rabanales, A. (1958). "Introducción al estudio del español de Chile. Determinación del concepto de chilenismo", en Boletín de filología, anexo № 1., pp. 205-302. Santiago de Chile: Universidad de Chile, Publicaciones del Instituto de Filología. Universitaria. 
Regueiro Rodríguez, M. ${ }^{a}$ L. (2010). La sinonimia. Madrid: Arco/Libros, Colec. Cuadernos de Lengua Española.

Sabino, M. A. (2006). "Falsos cognatos, falsos amigos ou cognatos enganosos? Desfazendo a confusão teórica através da prática", Alfa 50 (2), pp. 251-263.

Shipley, J. T. (1960). Playing with words, Englewood Cliffs: N. J., Prentice-Hall. Digitalizado en 2008.

Segarra Vals, J. J. (2010). Léxico psico(pato)lógico en la obra de Carlos Castilla del Pino. Valencia: Universitat de Valencia, Servei de Publicacións.

Torijano Pérez, J. Agustín. "Los neologismos por composición: acto y potencia”, en: Villar Díaz, Ma B., Hoyos, J. C. de, Dury, P., Makri-Morel, J. y Renner, V. (Université Lumière Lyon 2) (eds.): La néologie des langues romanes: nouvelles dynamiques et enjeux. Peter Lang, Frankfurt am Main, (en prensa).

Varo Varo, C. (2007). La antonimia léxica, Madrid: Arco / Libros, Colec. Bibliotheca Philologica.

Vita Pacheco, C. (2006). "Os conceitos de falsos amigos, falsos cognatos e heterossemânticos: a discussão de uma sinonímia". En Anais do III Congresso Brasileiro de hispanistas. Florianópolis, 2006, pp. 117-124: http://www.lle.cce.ufsc.br/congresso/trabalhos_lingua/Claudia\%20Pacheco\%20Vita.doc 